\title{
Brush border enzymes in coeliac disease: histochemical evaluation
}

\author{
J Mercer, M E Eagles, I C Talbot
}

\begin{abstract}
Two hundred and ninety four duodenal and jejunal mucosal biopsy specimens from patients with coeliac disease, treated and untreated, and other conditions were examined histologically and by histochemical staining for five peptidase and three disaccharidase enzymes to determine profiles of activity. Suppression of activity paralleled the histology with the following enzymes: lactase, trehalase, brush border endopeptidase, dipeptidyl peptidase II and isomaltase. Lactase, trehalase, and brush border endopeptidase were specifically suppressed in untreated coeliac disease and were diagnostically useful. Examination of a combination of enzymes is recommended.
\end{abstract}

Coeliac disease is diagnosed by the finding of subtotal villous atrophy on a jejunal biopsy specimen followed by recovery on a gluten free diet. Clinical recovery, however, may take time to establish and the histological assessment of a biopsy specimen may sometimes be difficult. Although subtotal villous atrophy has been regarded as an essential diagnostic feature, a few patients with less mucosal damage have been found to improve on a gluten free diet, ${ }^{1-4}$ and degrees of villous atrophy have been described in conditions other than coeliac disease. ${ }^{2}$ An additional technique which provides supportive evidence for the diagnosis would therefore be useful.

In 1956 Frazer described the disappearance of the toxic effect of gliadin peptides in coeliac disease after digestion with an extract of pig's intestinal mucosa and concluded that the handling of these peptides occurred in the mucosal wall. ${ }^{5}$ Since then there has been considerable interest in the enzymes of the small intestinal mucosa in patients with coeliac disease and various methods have been used to study many different enzymes. In biochemical assays on homogenised mucosa some authors have shown a reduction in peptidase ${ }^{67}$ and disaccharidase $\mathrm{e}^{7-11}$ activities in untreated coeliac disease. Biochemical assays, however, fail to take into account the fact that many of these enzymes have more than one location within the mucosa. ${ }^{12}$ Accurate location of enzymes can be achieved by electron microscopy and by immunocytochemistry, but immunoreactivity for lactase and sucrase-isomaltase has been shown to correlate poorly with enzyme activity. ${ }^{13}$

Histochemical techniques show both the location and activity of an enzyme and can be applied to small samples of tissue such as endoscopic biopsy specimens. The histochemical demonstration of enzyme loss in coeliac disease was first described by Padykula et al. $^{14}$ Several subsequent histochemical studies have shown a loss or reduction of both peptidase and disaccharidase enzymes in active coeliac disease, ${ }^{61215-19}$ and at least partial recovery on a gluten free diet has been found. ${ }^{12} 19$ Such studies can provide a useful assessment of mucosal damage in coeliac disease. $^{12}$

We have used histochemical techniques to assess the activity of three disaccharidase and five peptidase enzymes which are normally located in the upper small intestinal mucosa. Enzyme activity is related to both the histological appearances of the mucosa and to the clinical diagnosis. A simple grading system, which can easily be applied routinely, is used to assess enzyme activity.

\section{Methods}

Two hundred and ninety four biopsy specimens were obtained from 267 patients: 20 patients had more than one biopsy specimen taken. The specimens were taken for the diagnosis of clinically suspected coeliac disease, assessment of response to a gluten free diet, and investigation of anaemia, weight loss, diarrhoea, failure to grow in childhood, abnormal butterfat or xylose absorption tests, or a combination of these symptoms. The following information was recorded for each patient; age, sex, diet, duration of gluten free diet, symptoms at presentation and final diagnosis (from subsequent investigation and follow up). The patients were grouped on final diagnosis (table 1). A final diagnosis was not availble for every patient as some were lost to follow up and others continue to be investigated. All patients grouped as "normal" had both a histologically normal biopsy specimen and were found to have no clinically important illness as a result of clinical investigations. Biopsy specimens grouped as "other diagnoses not involving gastrointestinal tract" included those from

\section{Table 1 Clinical groups: diagnosis after investgation}

\begin{tabular}{lc}
\hline Group & $\begin{array}{l}\text { No of } \\
\text { cases }\end{array}$ \\
\hline Normal & 8 \\
Untreated coeliac disease & 34 \\
Cocliac on GFD & 37 \\
Other diagnoses affecting gastrointestinal tract & 39 \\
Other diagnoses not affecting gastrointestinal tract & 49 \\
\hline
\end{tabular}

GFD = gluten free diet. 
Table 2 Histochemical methods

\begin{tabular}{|c|c|c|c|}
\hline Enzyme & Substrate & Notes & Reference for method \\
\hline $\begin{array}{l}\text { Lactase } \\
\text { Isomaltase }\end{array}$ & $\begin{array}{l}\operatorname{IBF}(1,4) \\
\text { Isomaltose (3) }\end{array}$ & \multirow{3}{*}{$\begin{array}{l}\text { Synthetic substrate } \\
\text { Multistep method using } \\
\text { GOP-PMS-NBT (1) in agarose } \\
\text { Multistep method using } \\
\text { GO-PMS-NBT (1) in agarose } \\
\text { Coupling agent = Fast Blue B }\end{array}$} & $\begin{array}{l}\text { Lojda \& Kraml } 1971^{15} \\
\text { Lojda } 1967^{20}\end{array}$ \\
\hline Trehalase & Trehalose (4) & & Lojda $1965^{20}$ \\
\hline Dipeptidyl peptidase II (DPP II) & Lysyl-alanine-4MNA $(1,5)$ & & \multirow{2}{*}{$\begin{array}{l}\text { Gossrau } 1977^{21} \\
\text { Gossrau \& Lojda } 1980^{18} \\
\text { Lojda } 1979^{6} \\
\text { Lojda \& Gossrau } 1980^{17} \\
\text { Nachlas et al } 1960^{22} \\
\text { Lojda } 1979^{19}\end{array}$} \\
\hline $\begin{array}{l}\text { Dipeptidyl peptidase IV (DPP IV) } \\
\text { Aminopeptidase A (APA) } \\
\text { Aminopeptidase M (APM) } \\
\text { Brush border endopeptidase (BBE) }\end{array}$ & $\begin{array}{l}\text { Glycyl-proline-4MNA }(1,5) \\
\text { L-glutamyl-4MNA }(1,5) \\
\text { L-leucyl-4MNA }(1,5) \\
\text { Glutamyl-alanyl-alanyl- } \\
\text { alanine-4MNA }(1,5)\end{array}$ & $\begin{array}{l}\text { As above } \\
\text { As above } \\
\text { As above } \\
\text { Incubation on semipermeable } \\
\text { membrane }\end{array}$ & \\
\hline
\end{tabular}

(1) IBF $=5$-bromo-4-chloro-3-indolyl- $\beta$-D-fucoside

$4 \mathrm{MNA}=4$-methoxy-2-naphthylamide

GO-PMS-NBT = glucose oxidase-phenazine methosulphate-nitroblue tetrazolium.

(2) Sigma, Poole, Dorset

(3) Fluka, Glossop, Derbyshire

(4) Serva, Uniscience Ltd, London

(5) Bachem, Bubendorf, Switzerland

(6) Other chemical sources - agarose type VII - Sigma, Poole, Dorset

- Harris's haematoxylin - Ortho Diagnostics, High Wycombe, Bucks

patients who, after clinical investigation, hadfor example, iron deficiency anaemia due to non-gastrointestinal haemorrhage, menorrhagia, dietary anaemia, thyrotoxicosis, hypothyroidism, Sjögren's syndrome, depression and delayed puberty resulting from hormonal abnormalities. Those biopsy specimens grouped as "other diagnoses involving the gastrointestinal tract" included those from patients whose final diagnosis was Crohn's disease, ulcerative colitis, Menetrier's syndrome, cow's milk allergy, irritable bowel syndrome and diverticular disease. The age range of patients was 7 months to 89 years. Fifteen patients were under 1 year old, 59 patients were between 1 and 15 years, and the remaining 220 were adults.

Biopsy specimens were obtained either endoscopically or by Crosby capsule and were received fresh. Half of each biopsy specimen was fixed, paraffin wax embedded, routinely processed, and stained with haematoxylin and eosin for histological examination. The other half was orientated on cork under a dissecting microscope and frozen in isopentane cooled in liquid nitrogen. Samples were placed in airtight tubes and stored in liquid nitrogen until required.

\section{HISTOCHEMICAL TECHNIQUES}

Biopsy specimens were processed in batches of eight. Using cryostat sections $8 \mu \mathrm{m}$ thick, the unfixed sections (except those for lactase) were delipidised in equal parts of chloroform and acetone at $4^{\circ} \mathrm{C}$ for five minutes. Sections were incubated with the substrate appropriate to each enzyme, as described previously (table 2). ${ }^{61517-22}$ After incubation, sections for peptidases were rinsed in distilled water, chelated in $2 \%$ copper sulphate for five minutes, rinsed again and fixed in $10 \%$ formalin for five minutes, then washed and mounted in Aquamount. Sections for isomaltase and trehalase were washed in warm distilled water and then fixed and mounted as described for peptidases. Sections for lactase were rinsed, fixed in $10 \%$ formalin, counterstained with $0.1 \%$ nuclear fast red in 5\% aluminium sulphate, washed, dehydrated, and cleared and mounted in Xam. Negative controls were treated iden- tically but lacked only the substrate. All chemicals were of the highest grade (BDH, Poole, Dorset), unless otherwise stated (table 2).

Biopsy specimens were assessed histologically and grouped as follows: normal; minor abnormalities; partial villous atrophy; or subtotal villous atrophy. Histochemical staining was assessed both for intensity of staining and location of activity, using the grading scheme shown in fig 1.

One way analysis of variance was performed, first for enzyme grade with histological groups and secondly, for enzyme grade with clinical groups, for each of the enzymes studied. The Kruskal-Wallis test was performed using Minitab statistical software on a VAX computer. The test ranks all cases from all groups as a single series, calculates the median, the average rank and the " $Z$ " value for each group.

$$
\begin{gathered}
\mathrm{Z}=(\text { average rank }-(\mathrm{N}+1) / 2) / \mathrm{SQRT} \\
\left((\mathrm{N}+1)(\mathrm{N}) /\left(\mathrm{N}_{1}-1\right) / 12\right)
\end{gathered}
$$

where $N_{1}=$ number of observations for each group and $\mathbf{N}=$ total number of observations. " $Z$ " has an approximately normal distribution about the centre for each group with a mean of 0 and variance of 1 .

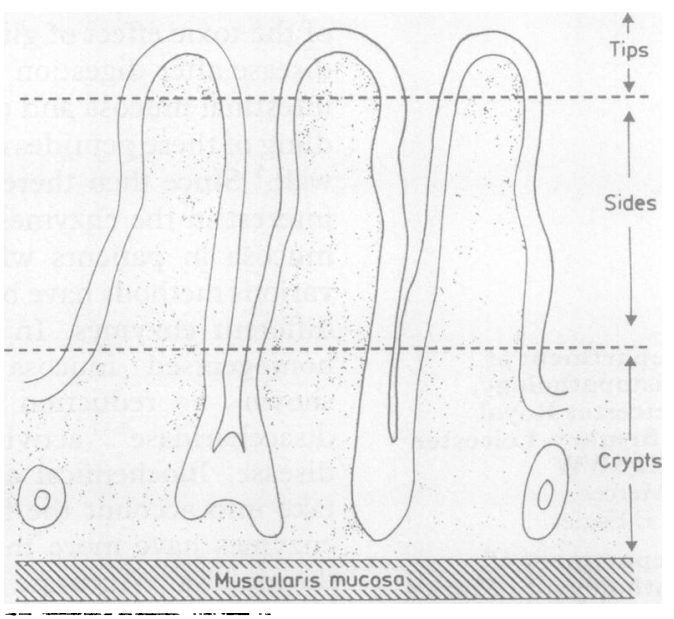

Figure 1 Grading system for assessment of enzyme activity. Grade $0=$ normal staining at all sites; grade 1 $=$ reduced staining, some tips only; grade $2=$ reduced staining on most tips; grade $3=$ all tips negative; grade $4=$ reduced staining of sides and tips negative, grade $5=$ sides and tips negative; grade $6=$ reduced staining in upper crypts only; grade $7=$ negative. 
Figure 2 Normal staining for $B B E-$ grade 0 .

Figure 3 Partial villous atrophy in coeliac disease; staining for lactase is negative - grade 7 .
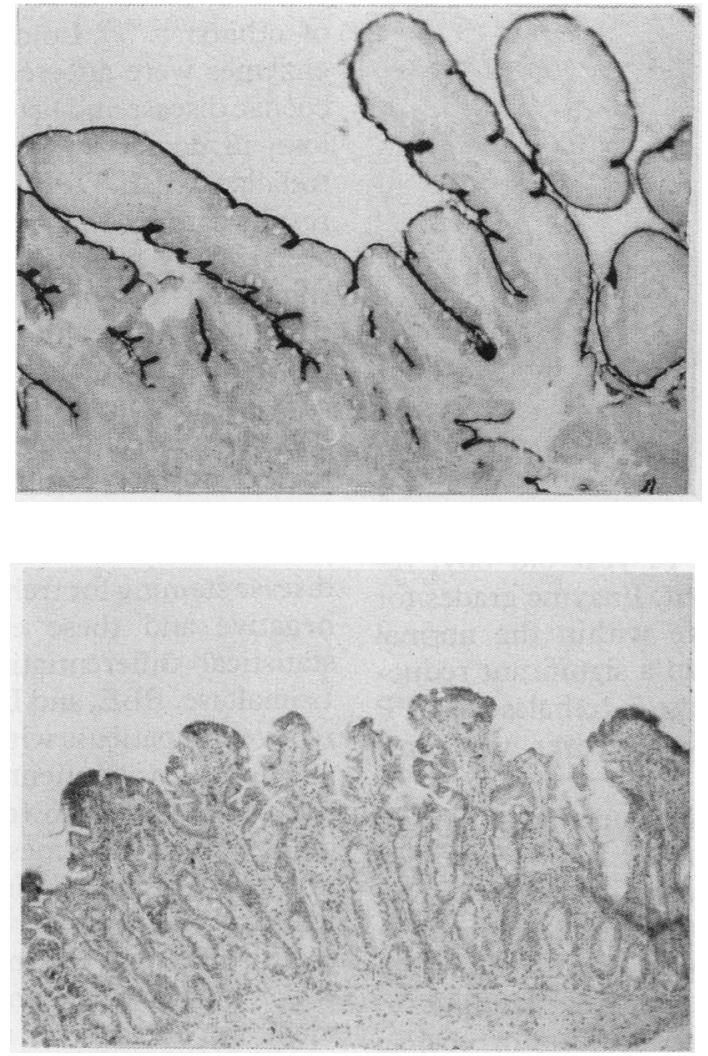

The result of analysis gives the KruskalWallis statistic " $H$ ", which has about the same distribution as $\chi^{2}$ with degrees of freedom $=$ $\mathrm{n}-1$, where $\mathbf{n}=$ the number of groups. Probability values for $\mathrm{H}$ were obtained from tables.

\section{Results}

In the normal cases all the enzymes studied showed well localised activity in the brush border of the upper third of the crypts, the sides, and the tips of the villi (fig 2). Both aminopeptidase enzymes also stained the lower two thirds of the crypt epithelium. In abnormal cases the enzyme staining for the peptidases and lactase was lost sequentially from the tips of villi, followed by the sides and crypts. Individual enzymes, however, were affected to a variable degree and examples are shown in figs 3 and 4 . The methods used for trehalase and isomaltase gave a more diffuse, generalised staining of the biopsy specimen and so could only be graded as positive (grade 0 ), reduced (grade 5), or negative (grade 7 ).

Analysis of variance between enzyme grade and histological group showed a highly significant correlation $(<0.001)$ for each of the following enzymes: lactase, trehalase, isomaltase, DPP II and BBE. The median enzyme

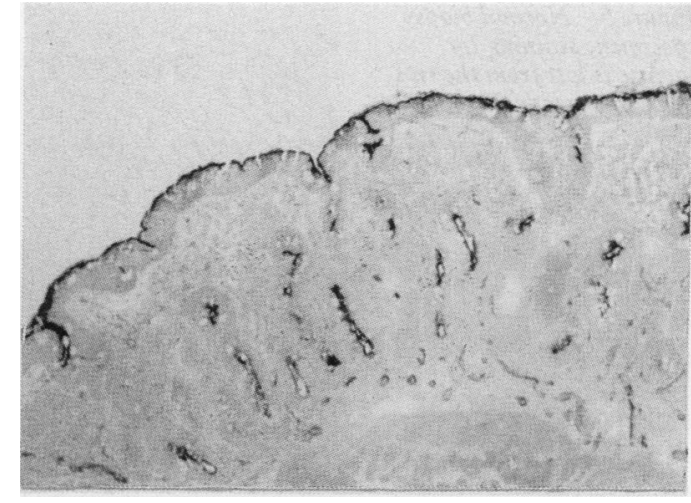

Figure 4 Subtotal villous atrophy in coeliac disease; staining for $A P A$ is positive - grade 0.

grades for each histological group are shown in table 3. Calculation of average rank (not shown) for each group showed ranking, in increasing order, from normal histology to subtotal villous atrophy for these enzymes. Biopsy specimens with subtotal villous atrophy showed the greatest enzyme loss, with a median grade of 7 for all three disaccharidases, and 6 , and 6.5 , respectively, for DPP II and BBE. Grades for the group with partial villous atrophy were slightly lower than those for subtotal villous atrophy but were significantly higher than for those of the groups with normal histology or minor changes. The best differentiation between groups was given by trehalase, followed, in order, by lactase, BBE, DPP II, and isomaltase.

A significant correlation was also shown between the same enzymes and the clinical diagnosis (lactase, trehalase, and BBE: $p<$ 0.001 ; isomaltase and DPP II: $p<0.05)$. The median enzyme grade for the diagnostic groups are shown in table 4 . There was considerable overlap between the enzyme grades for the normal, other disorders, and other gastrointestinal disorders groups but these were clearly distinguished from the two coeliac groups. The untreated coeliac patients gave the highest grades.

There was no significant correlation between enzyme grade and either histology or diagnosis for the enzymes DPP IV, APA, and APM (fig 4). No association was shown between age and enzyme grade or between sex and enzyme grade for any of the enzymes studied.

All of the biopsy specimens with subtotal villous atrophy and all except three of those with partial villous atrophy were from patients with coeliac disease. The three exceptions each presented with iron deficiency anaemia and an abnormal butterfat absorption test. One patient, a 41 year old man, also had $B_{12}$ deficiency and pernicious anaemia was sub-

Table 3 Analysis of variance of enzyme grade with histology

\begin{tabular}{|c|c|c|c|c|c|c|c|c|}
\hline \multirow[b]{2}{*}{ Histology } & \multicolumn{8}{|c|}{ Median enzyme grades } \\
\hline & Lactase & Trehalase & Isomaltase & $B B E$ & $D P P I I$ & $D P P I V$ & $A P A$ & $A P M$ \\
\hline $\begin{array}{l}\text { Normal } \\
\text { Mild changes } \\
\text { Partial villous atrophy } \\
\text { Subtotal villous atrophy } \\
\text { Number of observations } \\
\text { Kruskal-Wallis "H" statistic } \\
\text { Significance }\end{array}$ & $\begin{array}{c}3 \cdot 0 \\
3 \cdot 0 \\
7 \cdot 0 \\
7 \cdot 0 \\
244 \\
68 \cdot 47 \\
0.001\end{array}$ & $\begin{array}{c}0 \cdot 0 \\
5 \cdot 0 \\
7 \cdot 0 \\
7 \cdot 0 \\
272 \\
82 \cdot 42 \\
0 \cdot 001\end{array}$ & $\begin{array}{c}0 \cdot 0 \\
0 \cdot 0 \\
5 \cdot 0 \\
7 \cdot 0 \\
130 \\
24 \cdot 24 \\
0 \cdot 001\end{array}$ & $\begin{array}{c}3 \cdot 0 \\
2 \cdot 0 \\
5 \cdot 0 \\
6 \cdot 5 \\
173 \\
51 \cdot 81 \\
0.001\end{array}$ & $\begin{array}{c}3 \cdot 0 \\
3 \cdot 0 \\
4 \cdot 0 \\
6 \cdot 0 \\
217 \\
31 \cdot 40 \\
0.001\end{array}$ & $\begin{array}{l}1 \cdot 0 \\
0.0 \\
0 \cdot 0 \\
2 \cdot 0 \\
76 \\
3 \cdot 642 \\
\text { Not signif }\end{array}$ & $\begin{array}{l}1 \cdot 0 \\
0 \cdot 0 \\
0 \cdot 0 \\
2 \cdot 0 \\
78 \\
5 \cdot 140 \\
\text { Not signif }\end{array}$ & $\begin{array}{l}0.0 \\
0.0 \\
0.0 \\
0.0 \\
79 \\
1 \cdot 722 \\
\text { Not signif }\end{array}$ \\
\hline
\end{tabular}


Figure 5 Normal biopsy specimen; staining for lactase is lost from the tips of villi - grade 3.

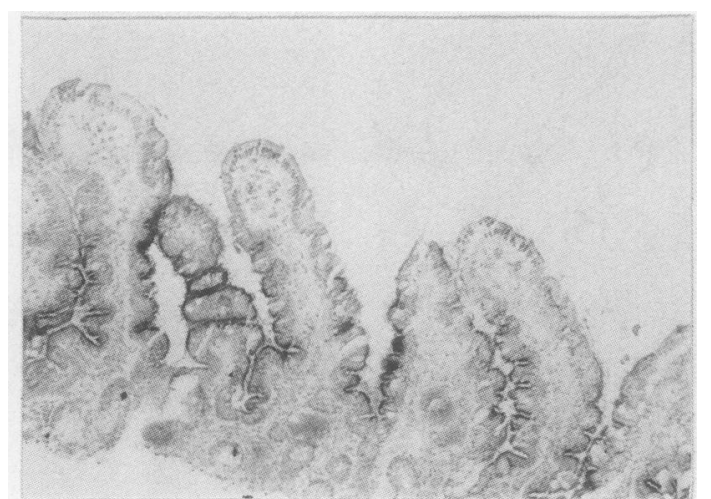

sequently diagnosed. The other two cases, a 39 year old woman and a 14 year old boy, responded to iron treatment. Enzyme grades for both male patients were within the normal range but the woman had a significant reduction in enzymes (isomaltase 5, trehalase 7, DPP II 7 and BBE 7). Lactase, however, was completely normal.

The biopsy specimens grouped as only mild histological changes included four cases in which coeliac disease was a possibility. The clinical details and enzyme grades for these patients are listed in table 5 . Case 1 showed a minimal reduction in enzymes, tending to confirm that the earlier diagnosis of coeliac disease was incorrect, as suspected clinically. Cases 2, 3, and 4 had pronounced enzyme loss. In cases 2 and 3 a diagnosis of coeliac disease was later confirmed, but case 4 improved on folate treatment alone and was discharged.

The patients with coeliac disease on a gluten free diet had various degrees of mucosal damage and the enzymes lactase, trehalase, isomaltase, DPP II and BBE showed a significant correlation with histological damage (results not shown). Twelve patients had one or more biopsy specimens after taking a gluten free diet in addition to the biopsy specimen before treatment. In seven of these the change in enzyme activity was in the same direction as the change in histology: four unchanged, two improved and one worse. In three cases there was some recovery of enzyme staining, although histology showed no significant difference from the biopsy specimen before treatment. Of the remaining two patients, one deteriorated histologically and the other improved, but enzyme activity was unchanged. No further analysis was attempted as the number of cases was too small.

\section{Discussion}

This demonstration of enzyme loss in the coeliac mucosa generally confirms the findings of others. ${ }^{6121419}$ Lojda found that individual enzymes were affected to different degrees in coeliac disease and listed the severity of enzyme loss, in decreasing order, as follows: lactase, trehalase, BBE, DPP IV, APA and APM..$^{12}$ Our results confirm that lactase, trehalase, and $\mathrm{BBE}$ are severely affected and our failure to show significant loss of DPP IV, APA, and APM suggests that they are variably lost or lost to a lesser extent. Others have found that APM was normal in some cases of coeliac disease, ${ }^{123}$ and Riecken $e t$ al, although using a different selection of enzymes, commented that APM was the least affected enzyme. ${ }^{24}$

In virtually all our cases of untreated coeliac disease staining for trehalase and for lactase was negative and these enzymes gave the best statistical differentiation of clinical groups. Isomaltase, $\mathrm{BBE}$, and DPP II were also grossly reduced in patients with coeliac disease.

The group of patients with coeliac disease on a gluten free diet showed slightly less depletion of the affected enzymes (lower grades) than the untreated group. This agrees with previous findings of a partial recovery of enzymes on treatment. ${ }^{12} 19$ In the small number of cases for which biopsy specimens before and after treatment were available, recovery seemed to be somewhat variable in individual patients. It was not known, however, how strictly these patients were adhering to their diets.

Previous histochemical studies have been generally based on a smaller number of biopsy specimens and statistical analysis has not been attempted. Our results suggest that some degree of enzyme loss from the tips of villi is within normal limits (table 4); some loss may also possibly occur in other gastrointestinal disorders. It is therefore important to select enzymes which show the highest level of significance in relation to clinical groups if histochemistry is to be used in the diagnosis of coeliac disease. In this study trehalase gave the strongest relation to groups $(\mathrm{H}=49 \cdot 82)$, followed by lactase $(\mathrm{H}=33.91)$, and $\mathrm{BBE}$ $(\mathrm{H}=19.53)$, all reaching a high level of significance $(\mathrm{p}<0.001)$.

The association between enzyme loss and the degree of histological mucosal damage has been noted previously. ${ }^{23} 25$ This relation is not unexpected as the most severe mucosal changesnamely, subtotal and partial villous atrophywere found in cases of coeliac disease. This finding is consistent with reports that enzyme loss is secondary to mucosal damage and reflects a lack of differentiation of enterocytes in the damaged mucosa. ${ }^{14} 24$

Table 4 Analysis of variance of enzyme grade with diagnosis

\begin{tabular}{|c|c|c|c|c|c|c|c|c|}
\hline \multirow[b]{2}{*}{ Diagnostic group } & \multicolumn{8}{|c|}{ Median enzyme grades } \\
\hline & Lactase & Trehalase & Isomaltase & $\boldsymbol{B B E}$ & DPPII & DPPIV & $A P A$ & $A P M$ \\
\hline $\begin{array}{l}\text { Normal } \\
\text { Non-gastrointestinal tract } \\
\text { disorders }\end{array}$ & $\begin{array}{l}3 \cdot 0 \\
2 \cdot 0\end{array}$ & $\begin{array}{l}0.0 \\
0 \cdot 0\end{array}$ & $\begin{array}{l}0 \cdot 0 \\
0 \cdot 0\end{array}$ & $\begin{array}{l}3 \cdot 0 \\
3 \cdot 0\end{array}$ & $\begin{array}{l}3 \cdot 5 \\
4 \cdot 0\end{array}$ & $\begin{array}{l}2 \cdot 0 \\
0 \cdot 0\end{array}$ & $\begin{array}{l}2 \cdot 0 \\
0 \cdot 0\end{array}$ & $\begin{array}{l}0.0 \\
0.0\end{array}$ \\
\hline $\begin{array}{l}\text { Other gastrointestinal tract } \\
\text { disorders }\end{array}$ & $3 \cdot 5$ & $0 \cdot 0$ & $5 \cdot 0$ & $2 \cdot 0$ & $3 \cdot 0$ & $1 \cdot 0$ & $1 \cdot 0$ & $0 \cdot 0$ \\
\hline $\begin{array}{l}\text { Coeliac on gluten free diet } \\
\text { Untreated coeliac } \\
\text { Number of observations } \\
\text { Kruskal-Wallis "H" statistic } \\
\text { Significance }\end{array}$ & $\begin{array}{c}7 \cdot 0 \\
7 \cdot 0 \\
149 \\
33.91 \\
0.001\end{array}$ & $\begin{array}{c}5 \cdot 0 \\
7 \cdot 0 \\
173 \\
49 \cdot 82 \\
0 \cdot 001\end{array}$ & $\begin{array}{c}5 \cdot 0 \\
5 \cdot 0 \\
104 \\
10 \cdot 83 \\
0 \cdot 05\end{array}$ & $\begin{array}{c}4 \cdot 0 \\
6 \cdot 0 \\
113 \\
19 \cdot 53 \\
0 \cdot 001\end{array}$ & $\begin{array}{c}3 \cdot 0 \\
5 \cdot 0 \\
133 \\
13 \cdot 28 \\
0 \cdot 05\end{array}$ & $\begin{array}{l}0 \cdot 0 \\
1 \cdot 0 \\
75 \\
0.7117 \\
\text { Not signif }\end{array}$ & $\begin{array}{l}0.0 \\
1.0 \\
77 \\
1.505 \\
\text { Not signif }\end{array}$ & $\begin{array}{l}0.0 \\
0.0 \\
78 \\
0.5827 \\
\text { Not signif }\end{array}$ \\
\hline
\end{tabular}


Table 5 Possible cases of coeliac disease with only minor histological abnormalities

\begin{tabular}{|c|c|c|c|c|c|c|}
\hline \multirow{2}{*}{$\begin{array}{l}\text { Case } \\
\text { No }\end{array}$} & \multicolumn{5}{|c|}{ Enzyme grades } & \multirow[b]{2}{*}{ Clinical details } \\
\hline & Lactase & Trehalase & Isomaltase & $B B E$ & $D P P I I$ & \\
\hline 1 & 3 & 0 & 0 & 0 & 0 & $\begin{array}{l}17 \text { year old female; coeliac diagnosed at age } 7 \text { months, off } \\
\text { GFD for } 5 \text { years at time of biopsy ? Not coeliac }\end{array}$ \\
\hline 2 & 7 & 7 & 5 & 6 & - & $\begin{array}{l}38 \text { year old female; diarrhoea, epigastric pain + anaemia } \\
\text { at time of biopsy. Repeat biopsy } 4 \text { months later - partial } \\
\text { villous atrophy Improved on GFD }\end{array}$ \\
\hline 3 & 7 & 7 & - & - & 7 & $\begin{array}{l}77 \text { year old female; abdominal pain, weight loss, } \\
\text { abnormal butterfat }+ \text { xylose absorption at time of } \\
\text { biopsy. Improved on GFD. Died two years later from } \\
\text { small bowel lymphoma }\end{array}$ \\
\hline 4 & 4 & 7 & 7 & 7 & 6 & $\begin{array}{l}64 \text { year old female; folate deficiency and abnormal } \\
\text { butterfat absorption at time of biopsy. Improved on } \\
\text { folate treatment and discharged without further } \\
\text { investigation }\end{array}$ \\
\hline
\end{tabular}

The exceptional cases, which showed enzyme loss disproportionate to histological changes, are of particular interest. The three patients with anaemia and partial villous atrophy, of which two had normal enzymes, are difficult to explain. Shiner in 1959 reported partial villous atrophy in association with folic acid deficiency, ${ }^{2}$ but neither iron deficiency nor pernicious anaemia are usually associated with clinically important mucosal damage. Cases 2, 3 , and 4 in table 5 had only minor histological damage but pronounced enzyme loss and probably all represent true cases of coeliac disease. In two of these subsequent recovery on a gluten free diet tended to confirm this. In case 4 the patient was discharged after improvement on folate treatment and the diagnosis remains open. Repeated sampling of the mucosa in one patient shows variation in the degree of histological damage ${ }^{2326}$ and our patients may have had more severe mucosal changes at adjacent sites. Enzyme assessment in these cases provided evidence to support a diagnosis of coeliac disease and the diagnosis may have been missed on histology alone.

The grading system used in this study assessed both the site and intensity of staining. Although the site of staining could not be assessed for trehalase and isomaltase, staining for lactase, BBE, and DPP II was frequently absent or reduced on the tips of villi in both clinically normal patients (table 4) and in histologically normal biopsy specimens (table 3). The site of staining loss therefore seems to be an important part of the assessment. In subtotal villous atrophy villi are virtually absent and so it is only possible to assess staining along the luminal surface and in the crypts. Staining of the luminal surface for lactase, BBE, and DPP II was invariably absent in subtotal villous atrophy so that assigning a grade to this area was never a problem. Absence of staining on the luminal surface was quite often associated with weak staining of the upper crypts, confirming previous findings that the greatest enzyme loss occurs from the luminal surface..$^{121423}$

Enzyme activity has been shown to vary with age, sex, and site of biopsy in biochemical assays. ${ }^{27} \mathrm{We}$ were unable to show any correlation with age or sex, but the small number of children in this study may be partly responsible for this. Biopsy specimens were obtained both endoscopically and via a Crosby capsule, but any effect of the difference in site was not analysed. Keane $e t$ al used both types of biopsy specimens and found that all sites from the second part of the duodenum to distal jejunum were adequate for enzyme assessment. ${ }^{27}$ All the enzymes used in this study have previously shown in both the jejunum and duodenum. ${ }^{15-19}$

In conclusion, our results suggest that the histochemical assessment of enzymes is a useful addition to routine histology in the diagnosis of coeliac disease and may occasionally direct attention to cases which would have been missed on histology alone. It also provides a baseline for assessing mucosal recovery after treatment. The choice of enzymes is important and our results show lactase, trehalase, and BBE to be the most useful. Although the disaccharidases are generally more severely affected than the peptidase enzymes, lactase deficiency is well known to occur as a primary enzyme defect and as an acquired phenomenon in many gastrointestinal disorders, and primary trehalase deficiency has also been described. ${ }^{28}$ Examination of a combination of enzymes is therefore recommended.

We thank the clinicians who cooperated in this study, especially Dr D Carr-Locke. We are also grateful to Dr Carole Jagger for her invaluable advice on statistical methods, and to Mrs Margaret Hornby for typing the manuscript.

1 Roy-Choudhury D, CookeWT, Tan DT, Banwell JG, Smits BJ. Jejunal biopsy: criteria and significance. Scand Gastroenterol 1966;1:57-74.

2 Shiner M. Small intestinal biopsy: diagnostic and research value. Proc Roy Soc Med 1959;52:10-4.

3 Egan-Mitchell B, Fottrell PF, McNicholl B. Early or precoeliac mucosa: development of gluten enteropathy. Gut 1981;22:65-9.

4 O'Farrelly C, Graeme-Cook F, Hourihane D O'B, Feighery C. Histological changes associated with wheat protein antibodies in the absence of villous atrophy. J Clin Patho 1987;40:1228-30.

5 Frazer AC. Discussion on some problem of steatorrhoea and reduced stature. Proc Roy Soc Med 1956;49:1009-13.

6 Lojda Z. Studies on dipeptidyl (amino) peptidase IV (glycyl-proline-naphthylamidase) II. Blood Vessels. Histochemistry 1979;59:153-66.

7 Sjostrom H, Noren O, Krasilnikoff PA, Gudmand-Hoyer E. Intestinal peptidases and sucrase in coeliac disease. Clin Chim Acta 1981;109:53-8.

8 Andersen KJ, Schjonsby H, Skagen DW. Jejunal mucosal enzymes in untreated and treated coeliac disease. Scand J enzymes in untreated and treat

9 O'Grady JG, Sterens FM, Keane R, et al. Intestinal lactase, sucrase, and alkaline phosphatase in 373 patients with sucrase, and alkaline phosphatase in 373 patient

10 Bramble MG, Zucoloto S, Wright NA, Record CO. Acute gluten challenge in treated adult coeliac disease: a morphometric and enzymatic study. Gut 1985;26:169-74.

11 Andersen KJ, Schjonsby H, Skagen DW, Haga HJ. Enzyme activities in jejunal biopsy samples from patients with adult coeliac disease with and without steatorrhoea. Scand $J$ Gastroenterol 1983;18:365-8.

12 Lojda Z. Proteinases in pathology. Usefulness of histochemical methods. J Histochem Cytochem 1981;29(3A): 
481-93.

13 Lojda Z, Smidova J, Kolinskja J, Kraml J. A comparative study of lactase and sucrase-isomaltase activities and immunoreactivities in jejunal biopsies of patients suffering from the malabsorption syndrome. Histochem $J 1984$; 16:373-6

14 Padykula HA, Strauss EW, Ladman AJ, Gardner FH. A morphological and histochemical analysis of the human jejunal epithelium in nontropical sprue. Gastroenterology $1961 ; 40: 735-65$

15 Lojda Z, Kraml J. Indigogenic methods for glycosidases III An improved method with 4-Cl-5-Br-3-Indolyl-B-Dfucoside and its application in studies of enzymes in the intestine, kidney and other tissues. Histochemie intestine, kidney

16 Lojda Z. The histochemical demonstration of peptidases by natural substances. Histochemistry 1979;62:305-23.

17 Lojda Z, Gossrau R. Study on aminopeptidase A. Histochemistry 1980;67:267-90.

18 Gossrau R, Lojda Z. Study on dipeptidyl peptidase II (DPP 11). Histochemistry 1980;70:53-76.

19 Lojda $Z$. The histochemical demonstration of brush border endopeptidase. Histochemistry 1979;64:205-21.

20 Lojda Z. Some remarks concerning the histochemical detection of disaccharidases and glucosidases. Histochemie 1965;5:339-60.

21 Gossrau R. Peptidasen. I. Histochemische Untersuchungen mit 2-Naphtylamiden und Hexazonium-p-rosanilin.

22 Nachlas MM, Mavis B, Rosenblatt D, Seligmas AM Improvement in histochemical localisation of leucine aminopeptidase with a new substrate, L-leucyl-4-methoxy-2-naphthylamide. Journal of Biophysical and Biochemical Cytology 1960;7:262-4.

23 Spiro HM, Filipe MI, Stewart JS, Booth CC, Pearse AGE Functional histochemistry of the small bowel mucosa in malabsorptive syndromes. Gut 1964;5:145-54.

24 Riecken EO, Stewart JS, Booth CC, Pearse AGE. A histochemical study on the role of lysosomal enzymes in idiopathic steatorrhoea before and during a gluten-free diet. Gut 1966;7:317-32.

25 O'Grady JG, Stevens FM, Keane R, et al. Intestinal lactase, sucrase and alkaline phosphatase in 273 patients with coeliac disease. J Clin Pathol 1984;37:298-301.

26 Scott BB, Losowsky MS. Patchiness and duodenal-jejunal variation of the mucosal abnormality in coeliac disease and dermatitis herpetiformis. Gut 1976;17:984-92.

27 Keane R, O'Grady JG, Sheil J, et al. Intestinal lactase, sucrase and alkaline phosphatase in relation to age, sex and site of intestinal biopsy in 477 Irish subjects. J Clin Pathol 1983;36:74-7.

28 Bergoz R, Vallotton M-C, Loizeau E. Trehalase deficiency. Prevalence and relation to single-cell protein food. Ann Nutr Metabol 1982;26:291-5. 